\title{
Bioaccessibility and Cell Metabolic Activity Studies of Antioxidant Low Molecular Weight Peptides Obtained by Ultrafiltration of $\alpha$-Lactalbumin Enzymatic Hydrolysates
}

\author{
Adriana Maite Fernández-Fernández¹, Eliane Dumay², Tomás López-Pedemonte, \\ Alejandra Medrano-Fernandez ${ }^{{ }^{*}}$ \\ ${ }^{1}$ Departamento de Ciencia y Tecnología de Alimentos, Facultad de Química, Universidad de la República, Montevideo, Uruguay \\ ${ }^{2}$ Ingénierie des Agropolymères et Technologies Emergentes, Équipe de Biochimie et Technologie Alimentaires, Université de \\ Montpellier, 2 Place Eugène Bataillon, Montpellier, France \\ Email: *amedrano@fq.edu.uy
}

How to cite this paper: FernándezFernández, A.M., Dumay, E., López-Pedemonte, T. and Medrano-Fernandez, A. (2018) Bioaccessibility and Cell Metabolic Activity Studies of Antioxidant Low Molecular Weight Peptides Obtained by Ultrafiltration of $\alpha$-Lactalbumin Enzymatic Hydrolysates. Food and Nutrition Sciences, 9, 1047-1065.

https://doi.org/10.4236/fns.2018.99077

Received: July 24, 2018

Accepted: September 7, 2018

Published: September 10, 2018

Copyright $\odot 2018$ by authors and Scientific Research Publishing Inc. This work is licensed under the Creative Commons Attribution International License (CC BY 4.0).

http://creativecommons.org/licenses/by/4.0/

\begin{abstract}
$\alpha$-lactalbumin ( $\alpha$-LA) might increase its antioxidant potential after hydrolysis. In particular, low molecular weight (LMW) peptides showed greater antioxidant capacity. Different hydrolysis conditions with Alcalase enzyme were optimized with a composite central design and surface methodology. Sample obtained after $0.1 \%$ (w/w enzyme:substrate), 60 min hydrolysis, ultrafiltrated with membranes of $3 \mathrm{kDa}$ (named $4 \mathrm{LMW}$ ), showed the greatest antioxidant values: $1.574 \pm 0.060$ and $1.636 \pm 0.076 \mu \mathrm{molTE} / \mathrm{mg}$ of protein for ABTS and ORAC-FL, respectively. Sample 4 LMW produced mild ACE inhibition capacity, $22 \%$ related to Captopril. 4 LMW was submitted to in vitro gastrointestinal conditions using $\alpha$-amylase, pepsin, pancreatin and bile-extract; its antioxidant capacity was enhanced by the shorter peptides released, confirmed by SE-HPLC. Antioxidant capacity of digested 4 LMW sample (D 4 LMW) was $1.743 \pm 0.086$ and $2.542 \pm 0.245 \mu \mathrm{molTE} / \mathrm{mg}$ of protein for ABTS and ORAC-FL, respectively, showing improvement on bioaccessibility. Intestinal cells viability was higher for D 4 LMW.
\end{abstract}

\section{Keywords}

$\alpha$-Lactalbumin, Alcalase Hydrolysis, Ultrafiltration, Bioactive Properties, Gastrointestinal Digestion Simulation, Cell Viability

\section{Introduction}

Antioxidants are substances present in foods that decrease the negative effects of 
reactive oxygen and nitrogen species which are produced under oxidative stress conditions [1]. Oxidative stress is caused by the production of free radicals from normal cellular metabolism of aerobic organisms. Free radicals are atoms or molecules that have at least one unpaired electron [2]. Aerobic organisms have endogen mechanisms to undergo free radicals' production but oxidative stress is displayed when there is a cellular disbalance caused by an overproduction of these compounds producing modifications on proteins, lipids and DNA, then cellular dysfunction [1]. Reactive oxygen species and oxidative stress are involved in diseases such as cancer, diabetes, ischemia, infection, Parkinson's disease, atherosclerosis and arthritis, among others [3].

Several studies have reported the antioxidant capacity of milk and its protein fractions (whey, caseins, lactoferrin, albumin) as well as peptides [4]; in particular, a milk peptide with high antioxidant capacity has been identified (Trp-Tyr-Ser-Leu-Ala-Met-Ala-Ser-Asp-Ile) [5]. Whey proteins have high cysteine content which is crucial for intracellular glutathione production [6] [7]. Other authors, Sadat et al. [8], studied $\alpha$-lactalbumin ( $\alpha$-LA) hydrolysis by thermolysin enzyme regarding antioxidant capacity and pointed out that peptides responsible for it presented tryptophan (Trp) and tyrosine (Tyr) located at the end of different peptides.

Hypertension is defined as a sustained elevated arterial pressure which is associated with an increased risk of developing heart disease [9]. Enzymatic hydrolysis of food proteins releases peptides with biological properties that are encrypted in the native structure [5] [10] [11]. One example is peptides with angiotensin-converting enzyme (ACE) inhibition capacity which is related to hypertension [5]. Peptides with this property are commonly obtained by trypsin and pepsin enzymatic hydrolysis, but alcalase, chymotrypsin, and pancreatin have also been used, among others. Some peptides with ACE inhibition capacity obtained from fermented milk with Lactobacillus helveticus have been identified (Val-Pro-Pro (VPP) and Ile-Pro-Pro (IPP)) [12]. Some have been found in different types of cheese where the most matured ones presented increased ACE inhibition capacity due to proteolysis [12]. In order to obtain a rich fraction of ACE inhibitory peptides from $\alpha$-LA and $\beta$-lactoglobulin hydrolysates, ultrafiltration has been used to separate low molecular weight peptides [11] [13]. In addition, peptides with ACE inhibitory capacity obtained from whey protein isolate enzymatic hydrolysis have also been studied [14], as well as peptides obtained from nondairy sources such as fermentation of lentils (phenolic compound generation) [15].

As it has already been mentioned, enzymatic hydrolysis represents a wide mechanism used for improving food bioactive properties by obtaining low molecular weight peptides. Proteins are one of the most sensible bioactive molecules to gastrointestinal tract conditions [16]. It is of most importance to take into account food bioaccessibility when it is expected to evaluate the effects of ingested foods [17] [18]. 
The gastrointestinal tract is formed by mouth, stomach, small intestine and colon. The first region (the mouth) is where food interacts with saliva which is a complex aqueous fluid of neutral $\mathrm{pH}$ and polymers, salts, buffers and digestive enzymes such as amylase. Moreover, foods also interact with tongue, teeth, palate, cheeks and throat [19] [20]. At the mouth, food reduces its particle size, hydrates and lubricates by mixing with saliva [18]. The second region is the stomach where food is degraded by acid fluids around a $\mathrm{pH}$ of 2 [19]. Gastric fluids are made up of mineral ions and other solutes as well as endogen and exogen active components such as proteins, surfactants and phospholipids [19]. Also, lipase and proteases digestive enzymes are excreted. At this point proteins start hydrolysing by pepsin under low $\mathrm{pH}$ values, causing an improvement of bioactive properties [11] [18]. As the proteins are hydrolysed, the peptides with bioactive properties encrypted in the native protein are released [5] [12] [21]. Later, food passes to the small intestine formed by three regions called duodenum, jejunum and ileum, where most absorption of bioactive compounds occurs. Partially digested food located in the stomach is mixed with alkaline fluids from the small intestine causing $\mathrm{pH}$ increase to neutral values. Intestinal fluids have digestive enzymes, bile salts, phospholipids, bicarbonate and other salts to achieve digestion and absorption processes by formation of mixed micelles at the small intestine that are capable of solubilize lipids, passing through mucosa till reaching enterocyte surface where they are absorbed. Some hydrophilic bioactive compounds without any apolar groups could associate with mixed micelles [19].

Hollebeeck et al. [17] optimized an in vitro digestion protocol using response surface methodology with the objective of developing a way to simulate digestion. Digestion simulation consists of a first stage (saliva stage) in which $\alpha$-amylase enzyme is present, followed by a gastric stage (stomach) with pepsin enzyme and low $\mathrm{pH}$, and a last stage (duodenal) in which pancreatin and bile are present [17]. This simulation mimics in vivo digestion process being capable of evaluating bioaccessibility of potentially bioactive compounds till reaching small intestine where most of the absorption occurs. For this purpose, cell studies are needed. In vitro studies with cells of intestinal epithelium is a recognized way to mimic human intestinal epithelium absorption because of its tight junctions located at the apical side, cell systems of carrier-mediated transport, its microvillus structure and the expression of similar brush border membrane peptidases to human ones [22].

In a previous study [10], $\alpha$-LA hydrolysates were obtained with Alcalase through different hydrolysis conditions then characterized. From those hydrolysates it was concluded that the hydrolysate with $0.1 \%(\mathrm{w} / \mathrm{w} \%)$ enzyme:substrate ratio and 60 minutes of reaction time was the one presenting the highest antioxidant capacity associated with greater percentage of hydrolysis. It was then the interest of the present study to investigate the properties of Low Molecular Weight (LMW) hydrolysates separated by ultrafiltration and its bioactive properties (antioxidant and antihypertensive) as well as the evaluation of the effect of 
the gastrointestinal digestion by in vitro simulation on antioxidant capacity and cell metabolic activity.

\section{Materials and Methods}

\subsection{Materials}

Protein isolate of $\alpha$-lactalbumin (Biopure-lactoalbumin ${ }^{\mathrm{TM}}$ ) was provided by $\mathrm{Da}$ visco Food International Inc. (Le Sueur, MN, USA). Alcalase was provided by Novozymes Biopharma US Inc (Alcalase ${ }^{\circledR} 2.4 \mathrm{~L}$, Proteinase from Bacillus Licheniformis, Subtilisin A). Buffer salts $\mathrm{Na}_{2} \mathrm{HPO}_{4}$ (Mallinckrodt) and $\mathrm{NaH}_{2} \mathrm{PO}_{4}$ came from J. T. Baker. Folin reagent was purchased from Sigma Aldrich (St. Louis, MO). For antioxidant assays: 2,20-azinobis-(3-ethylbenzothiazoline-6-sulfonic acid) diammonium salt (ABTS), 6-hydroxy-2,5,7,8-tetramethylchroman-2-acid (Trolox), fluorescein (FL) disodium salt and 2,20-azobis(2-methylpropionamidine) dihydrochloride (AAPH) were obtained from Sigma Aldrich (St. Louis, MO), and potassium persulphate was from J. T. Baker. Histidil-hipuril-leucine (HHL) was purchased from Sigma Aldrich (St. Louis, MO) for performing angiotensin converting enzyme (ACE)-inhibition assay. To carry out digestion studies, $\alpha$-amylase, pepsin and pancreatin came from Sigma Aldrich (St. Louis, MO).

To carry out cell studies, High-glucose Dulbecco's modified Eagle medium (DMEM) with L-glutamine and pyruvate (Phenol red-DMEM), High-glucose Dulbecco's modified Eagle medium without L-glutamine neither pyruvate (Phenol red-free DMEM), Dulbecco's phosphate-buffered saline (DPBS) $\pm \mathrm{Ca}^{2+}$ and $\mathrm{Mg}^{2+}$, Hank's Balanced Salt Solution (HBSS), penicillin-streptomycin mixture, MEM non-essential amino acid and foetal bovine serum (FBS) were purchased from Life Technologies (Villebon-sur-Yvette, France). For cell metabolic activity determination (MTT assay), 3-(4,5-dimethyl-2-thiazolyl)-2,5-diphenyl tetrazolium bromide (MTT) and dimethyl sulfoxide (DMSO) were purchased from Sigma.

\subsection{Optimization of $\alpha$-LA Hydrolysis}

Optimization of hydrolysis process was carried out as in Fernández-Fernández et al. [10] where a composite central design was used [23] based on a response surface model, full factorial design. Briefly, arrangement of seven hydrolysates was generated. Enzymatic hydrolysis reaction was evaluated by determining ABTS and ORAC-FL values, as the response variables, with the variation of two factors as independent variables, enzyme:substrate ratio $(\mathrm{r})(\% \mathrm{w} / \mathrm{w})$ and time $(\mathrm{t})$ (minutes), at two levels each $(0.0050 \%$ and $0.1000 \% \mathrm{w} / \mathrm{w}, 0$ and 60 minutes, respectively), and three repeats of the central point $(0.0525 \% \mathrm{w} / \mathrm{w}$ and 30 minutes). The equation for the proposed model of response variables ABTS and ORAC-FL (Yi) is shown in Equation (1):

$$
\mathrm{Yi}=\beta_{0}+\beta_{1} \mathrm{r}+\beta_{2} \mathrm{t}+\beta_{1,2} \mathrm{r} \times \mathrm{t}+\mathcal{E}
$$

where $\beta_{0}$ is the regression coefficient for the intercept point; $\beta_{1}$ and $\beta_{2}$ are the linear regression coefficients; $\beta_{1,2}$ is the regression coefficient for the interaction between the independent variables (factors $\mathrm{r}$ and $\mathrm{t}$ ); and $\varepsilon$ is the variable error. 
Model parameters were calculated with Statgraphic Plus version 5.1 program by multiple linear regression (MLR).

\subsection{Ultrafiltration of $\alpha$-LA Hydrolysates}

Enzymatic hydrolysis reaction was performed using Alcalase enzyme $(1.158 \mathrm{mg} / \mathrm{mL}$, enzymatic activity $\geq 2.4 \mathrm{AU} / \mathrm{g})$ with $8 \%(\mathrm{w} / \mathrm{V})$ of protein isolate $(\alpha$-LA) in phosphate buffer solution $100 \mathrm{mM} \mathrm{pH} 7$ and was incubated in a water bath at $30^{\circ} \mathrm{C}$ with agitation of $150 \mathrm{rpm}$. After incubation time (as in Section 2.2), reaction was stopped by heating at $100^{\circ} \mathrm{C}$ for 10 minutes. Ultrafiltration was carried out using an Amicon membrane (cut-off of $3 \mathrm{kDa}$, Merk Millipore) to separate peptides of low molecular weight (LMW) from high molecular weight (HMW). For each hydrolysate, two separate fractions were obtained: LMW and HMW fractions. From each of the seven samples, two fractions were obtained resulting in 14 samples (7 LMW and $7 \mathrm{HMW}$ ). Samples were frozen, lyophilized and stored at $-20^{\circ} \mathrm{C}$ for subsequent analysis.

\subsection{Characterization of $\alpha$-LA Hydrolysates}

Protein content determination was performed by Lowry method [24] using solutions of $0.3 \mathrm{mg} / \mathrm{mL}$ of each hydrolysate fraction prepared in phosphate buffer $10 \mathrm{mM} \mathrm{pH} \mathrm{7.4.} \mathrm{For} \mathrm{solubility} \mathrm{determination} 10 \mathrm{mg} / \mathrm{mL}$ solutions of each hydrolysate fraction were prepared in the same phosphate buffer by 15 minutes of gentle magnetic agitation followed by centrifugation at 10,000 $\mathrm{g}$ for 10 minutes then determination of protein content in the supernatant by Lowry method.

SE-HPLC analysis was performed as described by Molina Ortiz [25] using a Shimadzu, SPD-20A detector and LC-10AT pump equipment detecting at $280 \mathrm{~nm}$. Hydrolysates fractions were eluted in a Molecular Exclusion Column BioSep-Sec 2000 with an isocratic flow of $1 \mathrm{~mL} / \mathrm{min}$ and phosphate buffer $50 \mathrm{mM}(\mathrm{pH} 6.8)$ $0.5 \%$ of SDS as mobile phase. Each sample was prepared in mobile phase in a concentration of $2 \mathrm{mg} / \mathrm{mL}$. Hydrolysis percentage was determined by quantifying $\alpha$-LA in each hydrolysate with $\alpha$-LA calibration curve.

\subsection{In Vitro Digestion}

Selected sample with greater antioxidant capacity, sample 4 LMW was submitted to in vitro digestion (D $4 \mathrm{LMW}$ ) by the gastrointestinal digestion simulation model described by Hollebeeck et al. [17]. In vitro digestions were performed in $50 \mathrm{~mL}$ Erlenmeyer flasks in water bath at $37^{\circ} \mathrm{C}$ and $200 \mathrm{rpm}$ of agitation. This simulation model has three successive stages. First stage corresponds to salivary stage in which $\alpha$-amylase stock solution ( 90 units $/ \mathrm{mL}, 0.43 \mathrm{~mL}$ ) and $10 \mathrm{~mL}$ of phosphate buffer $10 \mathrm{mM} \mathrm{pH} 6.9$ were added to $200 \mathrm{mg}$ of 4 LMW lyophilized hydrolysate. Incubation took place in a water bath at $37^{\circ} \mathrm{C}$ for 5 minutes and $200 \mathrm{rpm}$ of agitation. Stage two corresponds to gastric stage in which pepsin (71.2 units $/ \mathrm{mL}$ ) freshly prepared in $\mathrm{HCl} 0.1 \mathrm{M}$ was added to the same phosphate buffer brought to $\mathrm{pH} 2.0$ with $\mathrm{HCl} 1 \mathrm{M}(22.73 \mathrm{~mL}$ final volume, $12.3 \mathrm{~mL}$ of vo- 
lume added in the second stage). Incubation was carried out in the same conditions for 90 minutes. Third stage corresponds to duodenal stage in which pancreatin and bile extract $(9.2 \mathrm{mg}$ pancreatin and $55.2 \mathrm{mg}$ bile extract $/ \mathrm{mL}$ final concentrations) were added as well as the same phosphate buffer brought to $\mathrm{pH}$ 7.0 with $\mathrm{NaHCO}_{3} 0.1 \mathrm{M},(30.09 \mathrm{~mL}$ final volume, $7.36 \mathrm{~mL}$ of volume added in the third stage). Incubation was carried out in the same conditions for $150 \mathrm{mi}-$ nutes. After finishing stage three, the enzymes were inactivated by heating in a water bath at $90^{\circ} \mathrm{C}$ for 10 minutes. Then, digestion samples were centrifuged at $10,000 \mathrm{rpm}$ for 10 minutes and supernatant was separated, frozen and lyophilized for further analysis.

\subsection{Antioxidant Capacity}

Antioxidant capacity was determined by electron transfer (ET) and hydrogen atom transfer (HAT) methods ABTS and ORAC-FL, respectively. ABTS was performed based on the method described by Re et al. [26] with some modifications [10] measuring absorbance at $734 \mathrm{~nm}$. Dose-response curves were constructed to calculate $\mathrm{IC}_{50}$ from the curve \% Inhibition vs. Protein $(\mathrm{mg} / \mathrm{mL}$ ) (from 0.25 to $5 \mathrm{mg} / \mathrm{mL}$ of protein). A logarithmic function was obtained in order to calculate the corresponding protein concentration which is able to inhibit $50 \%$ of ABTS radicals. Inhibition percentage was calculated according to Equation (2):

$$
\% \text { Inhibition }=\frac{A_{\text {control }}-A_{\text {antioxidant }}}{A_{\text {control }}}
$$

where $A_{\text {control }}$ is the absorbance of $3 \mathrm{~mL}$ of ABTS in buffer with $30 \mu \mathrm{L}$ of buffer and $A_{\text {antioxidant }}$ is the absorbance of $3 \mathrm{~mL}$ of ABTS in the same phosphate buffer with $30 \mu \mathrm{L}$ of Trolox or sample.

ORAC-FL was performed as described by Ou et al. [27] modified by Dávalos, Bartolomé and Gómez-Cordovés [28]. In this assay a fluorescent probe (FL) is oxidized by an oxygen radical generator (AAPH) lowering its fluorescence intensity. Fluorescence measurements were displayed at $485 \mathrm{~nm}$ and $520 \mathrm{~nm}$ of excitation and emission wavelengths, respectively, at $37^{\circ} \mathrm{C}$ for 104 minutes in the equipment Varioskan ${ }^{\circledR}$ Flash. Briefly, hydrolysates fractions and reagents were prepared in phosphate buffer $75 \mathrm{mM} \mathrm{pH}$ 7.4. Each well had a final volume of $200 \mu \mathrm{L}: 120 \mu \mathrm{L}$ of $1.17 \mathrm{mM}$ fluorescein solution (70 $\mathrm{nM}$ final concentration), $60 \mu \mathrm{L}$ of AAPH (12 $\mathrm{mM}$ final concentration) and $20 \mu \mathrm{L}$ of antioxidant substance (Trolox or sample). All samples' solutions were prepared at least in duplicate and each one of the preparations was tested at least in triplicate. The area under the curve (AUC) of Fluorescence vs Time was calculated according to Equation (3):

$$
\mathrm{AUC}=1+\sum_{i=1}^{i=104} f_{i} / f_{0}
$$

where $f_{0}$ is the fluorescence at 10 minutes of incubation at $37^{\circ} \mathrm{C}$ and $f_{i}$ is the fluorescence measured every minute, for 104 minutes. Curves of Fluorescence vs 
Time were normalized to the curve of the blank calculating the net AUC as the difference between $\mathrm{AUC}_{\text {antioxidant }}$ (Trolox or sample) minus $\mathrm{AUC}_{\text {blank }}$. Trolox calibration curve (net $\mathrm{AUC}_{\text {Trolox }}$ vsnTE ( $\mu$ mol TE, Trolox equivalents)) was constructed in order to calculate samples antioxidant capacity ( $\mu \mathrm{mol} \mathrm{TE} / \mathrm{mg}$ of protein). Besides punctual measurements, $\mathrm{IC}_{50}$ values were obtained by constructing the curve nTE vs [Protein] $(\mathrm{mg} / \mathrm{mL})$ to obtain a logarithmic function from which it could be calculated the concentration of protein correspondent to $50 \%$ inhibition of peroxyl radicals.

\subsection{Antihypertensive Activity}

Antihypertensive activity was determined as described by Cushman and Cheung [29] modified by Kim et al. [30] which consists of evaluating the inhibition of angiotensin converting enzyme (ACE). Briefly, samples were prepared as described by Fernández-Fernández et al. [10] in a concentration of $5 \mathrm{mg} / \mathrm{mL}$. Assay buffer (borate buffer $0.2 \mathrm{M}$ and $\mathrm{NaCl} 2 \mathrm{M}, \mathrm{pH}$ 8.3), mili Q water and HHL $5 \mathrm{mM}$ was added to the sample. Eppendorf tubes were incubated at $37^{\circ} \mathrm{C}, 700 \mathrm{rpm}$, for 5 minutes, and ACE was added in cold $(0-10 \mathrm{mU})$. Same tubes were incubated at $37^{\circ} \mathrm{C}, 700 \mathrm{rpm}$, for 30 minutes and then incubated at $90^{\circ} \mathrm{C}$ for 10 minutes. Finally, colour reagent and potassium phosphate buffer $0.2 \mathrm{M} \mathrm{pH} 8.3$ were added, samples were centrifuged at $20^{\circ} \mathrm{C}, 6000 \mathrm{rpm}$, for 10 minutes and supernatant absorbance was measured at $382 \mathrm{~nm}$. ACE inhibition percentage was calculated as shown in Equation (4):

$$
\% \text { ACE Inhibition }=100 *\left[1-\left(\frac{A_{S}-A_{0 S}}{A_{\max }-A_{0 \max }}\right)\right]
$$

where $A_{s}$ is the absorbance of sample with ACE, $A_{0 s}$ is the absorbance of sample without ACE, $A_{\max }$ is the absorbance in the absence of sample and $A_{0 \max }$ is the absorbance without sample and ACE.

\subsection{Cell Studies}

Cell metabolic activity (or cell viability; MTT assay) of TC7-cells was determined after $1 \mathrm{~h}$ incubation in the presence of HBSS (control), the hydrolysate or the in vitro digestion of the hydrolysate that presented greater antioxidant capacity, sample $4 \mathrm{LMW}$ and its digestion (D $4 \mathrm{LMW}$ ), respectively.

TC7-cells (passage 42 - 47) were routinely grown according to Benzaria et al. [31] [32] using $75 \mathrm{~cm}^{2}$ cell culture flasks in phenol red-DMEM culture medium supplemented with penicillin-streptomycin, MEM non-essential amino acids and heat-inactivated FBS. TC7-cells were seeded in sterile 12-well Trans well plates with Thin Cert inserts at a density of $1.25 \times 10^{5}$ cells/well and cultivated at $37^{\circ} \mathrm{C}$ and $8 \% \mathrm{CO}_{2}, 100 \% \mathrm{RH}$ (relative humidity) for 17 days until cell-confluence was reached as assessed by transepithelial electrical resistance (TEER) measurement before deposing the samples on the cells.

Samples were prepared in HBSS at concentrations of 1,5 and $10 \mathrm{mg} / \mathrm{mL}$ pro- 
tein. For the hydrolysate (4 LMW) and its gastro-intestinal digestion (D 4 LMW), 26.35 and $61.26 \mathrm{mg}$ of dry powder were weighted for $1 \mathrm{~mL}$ of HBSS, corresponding to $20 \mathrm{mg} / \mathrm{mL}$ of protein for both samples $(75.9 \%$ and $32.65 \%$ of protein, respectively). A volume of $500 \mu \mathrm{L}$ sample solutions were deposed on the cells and incubated for $1 \mathrm{~h}$ at $37^{\circ} \mathrm{C}$ and $8 \% \mathrm{CO}_{2}, 100 \% \mathrm{RH}$. After incubation, the apical TC7-culture media in the cell-wells were taken out and MTT assay was performed by adding $500 \mu \mathrm{L}$ MTT reagent $(0.15 \mathrm{mg} / \mathrm{mL}$ in FBS-free phenol red-free DMEM) to TC7-cells [31] [32]. MTT is reduced into Formazan ${ }^{\circledR}$ by a succinate deshydrogenase in living cells. The cell ability to reduce MTT provides an indication of mitochondrial integrity, and therefore of cell metabolic activity or cell viability. After $3 \mathrm{~h}$ incubation with MTT, determination was carried out by taking out MTT reagent from the cell-wells and by adding $500 \mu \mathrm{L}$ of DMSO to each well with subsequent incubation at $37^{\circ} \mathrm{C}$ for 30 minutes for cell lysing and Formazan ${ }^{\circledR}$ recovering.

Amounts of $100 \mu \mathrm{L}$ lysate were then transferred into 96-well plates to measure Formazan ${ }^{\circledR}$ absorbance at $570 \mathrm{~nm}$ in a microplate reader, after half diluting with DMSO. Viability percentage was calculated by taking the absorbance value of the control (HBSS) as $100 \%$.

\subsection{Statistical Analysis}

All the measurements were determined at least in triplicate. Results were expressed as mean values \pm standard deviation. One-way analysis of variance (ANOVA) and pos-hoc Tukey test was applied to determine significant differences between values $(\mathrm{p}<0.05)$. Statistical analysis was done using Infostat $v$. 2015 and Statgraphic Plus v. 5.1 programs.

\section{Results and Discussion}

Conditions of hydrolysis and characteristics of hydrolysates are shown in Table 1.

\subsection{Characterization of LMW $\alpha$-LA Hydrolysates}

Protein content and hydrolysis percentage were determined in the low molecular weight (LMW) fractions of samples 1 to 7 with the exception of sample 3, where hydrolysis conditions led to gelation. Gelification probably took place be due to a combination of factors such as: lower enzyme to protein ratio; lower hydrolysis rate; time and temperature of hydrolysis. For this reasons results of sample 3 are not included in Table 1 . It could be observed that protein content measurements tended to increase with factors time of hydrolysis and $r$ (enzyme to substrate ratio, see Table 1). As expected, for ultrafiltrated LMW hydrolysates, hydrolysis percentages determined by SE-HPLC were approximately 0 for samples with 0 minutes of reaction; no significant differences $(\mathrm{p}<0.05)$ were found between samples 5, 6 and 7 which have the same reaction conditions. Sample 4 LMW had no significant differences in hydrolysis percentage compared to samples 
Table 1. Results of protein content and hydrolysis percentage of low molecular weight (LMW) fractions of $\alpha$-LA hydrolysates according to different enzyme:substrate ratio (r, \% $\mathrm{w} / \mathrm{w})$ and time (t, min).

\begin{tabular}{lccccc}
\hline \multirow{2}{*}{ Sample } & \multicolumn{2}{c}{ Factors } & & \% Protein & \% Hydrolysis \\
\cline { 2 - 3 } & $\mathrm{r}$ & $\mathrm{t}$ & & $0^{\mathrm{a}}$ \\
\hline 1 LMW & 0.0050 & 0 & $56.0^{\mathrm{a}}$ & $3^{\mathrm{a}}$ \\
2 LMW & 0.1000 & 0 & $59.0^{\mathrm{a}}$ & - \\
3 LMW & 0.0050 & 60 & - & $56^{\mathrm{b}}$ \\
4 LMW & 0.1000 & 60 & $75.9^{\mathrm{c}}$ & $61^{\mathrm{b}}$ \\
5 LMW & 0.0525 & 30 & $70.2^{\mathrm{b}, \mathrm{c}}$ & $65^{\mathrm{b}}$ \\
6 LMW & 0.0525 & 30 & $63.4^{\mathrm{a}, \mathrm{b}}$ & $56^{\mathrm{b}}$ \\
7 LMW & 0.0525 & 30 & $85.7^{\mathrm{d}}$ & \\
\hline
\end{tabular}

Results are expressed as the means \pm SD $(n=6)$. ANOVA analysis was made by column using Tukey test. Means in the same column with different letters state significant differences $(\mathrm{p}<0.05)$.

5, 6 and 7 stating that short peptides resulting from hydrolysis were separated correctly by ultrafiltration.

Other authors [33] treated whey protein isolate with chymotrypsin, pepsin and trypsin reaching lower percentages of hydrolysis. Alcalase hydrolysates appear to be more hydrolyzed than those of digestive enzymes, possibly because of its unspecificity [33] producing a great quantity of short peptides with bioactive properties [12] [34]. Nevertheless, digestive enzymes could enhance hydrolysis improving antioxidant capacity [10]. LMW hydrolysate from sample 4 to 7 showed similar \% hydrolysis but in all cases higher than their non-ultrafiltrated counterparts which showed values below 31 [10].

\subsection{Antioxidant Capacity of LMW $\alpha$-LA Hydrolysates}

ABTS and ORAC-FL assays were the selected methods for evaluating the relationship between the factors enzyme:substrate ratio and time of reaction with the antioxidant capacity. The coefficients obtained from multiple linear regression analyses are shown in Table 2. ABTS and ORAC-FL response variables did not show similar behaviour. The coefficient values of both response variables showed a positive effect on the factor time of reaction and only a positive effect on factor enzyme:substrate ratio for ORAC-FL. The factor enzyme:substrate ratio was discarded for ABTS because of showing a p-value higher than 0.01 (non-significant). As to the model, for ABTS $\mathrm{R}^{2}$ was close to 1 so it can be deducted that the variation of the antioxidant capacity with the factors fit the model adequately $(\mathrm{p}<0.01)$. However, in the case of ORAC-FL $\mathrm{R}^{2}$ was lower than for ABTS but the model is adequate $(\mathrm{p}<0.01)$. Figure 1 shows surface plots of the antioxidant capacity by ABTS and ORAC-FL methods (response variables), as a function of enzyme:substrate ratio $(0.0050 \%-0.1000 \% \mathrm{w} / \mathrm{w})$ and of time (0 - 60 minutes). Both plots show similar tendencies augmenting the 
Table 2. Coefficients of the Equation (1) and statistics obtained for the response surface model by multiple linear regression analysis, for ABTS and ORAC-FL response variables for LMW samples.

\begin{tabular}{ccc}
\hline Terms & $\begin{array}{c}\text { ABTS value } \\
(\mu \text { mol Trolox } / \text { mg protein })\end{array}$ & $\begin{array}{c}\text { ORAC-FL value } \\
(\mu \text { mol Trolox } / \text { mg protein })\end{array}$ \\
\hline $\begin{array}{c}\text { Constant } \\
\text { Enzyme:substrate ratio } \\
(\mathrm{w} / \mathrm{w})(\mathrm{r})\end{array}$ & 0.2196 & 0.6622 \\
Time (minutes) $(\mathrm{t})$ & - & 3.9581 \\
$\mathrm{R} \times \mathrm{t}$ & 0.0424 & 0.0104 \\
$\mathrm{R}^{2}$ & -0.1985 & - \\
$\mathrm{p}$ & 0.9339 & 0.8810 \\
\hline
\end{tabular}

r: enzyme:substrate ratio; t: time; $\mathrm{R}^{2}$ : regression coefficient; $\mathrm{p}$ : $\mathrm{p}$-value for the unfit of the model (coefficients were $\mathrm{p}<0.01$ ).

antioxidant capacity with time, presenting a maximum for the conditions of sample $4 \mathrm{LWM}(0.1000 \mathrm{w} / \mathrm{w}$ and 60 minutes). Sample $4 \mathrm{LMW}$ antioxidant value was $1.574 \pm 0.060$ and $1.636 \pm 0.076 \mu \mathrm{mol} \mathrm{TE} / \mathrm{mg}$ of protein, compared to $\alpha$-LA $0.191 \pm 0.007$ and $0.159 \pm 0.011 \mu \mathrm{mol} \mathrm{TE} / \mathrm{mg}$ of protein, for ABTS and ORAC-FL antioxidant capacity, respectively. Sample 4 LMW had 8.2 and 10.2 times more antioxidant capacity for ABTS and ORAC-FL, respectively, than $\alpha$-LA. This sample values of antioxidant capacity differed greatly from other samples, showing increased antioxidant power. In our previous work, sample 4 presented $1.015 \pm 0.042$ and $1.495 \pm 0.114 \mu \mathrm{mol} \mathrm{TE} / \mathrm{mg}$ of protein in which case sample 4 LMW shows 1.55 and 1.09 times more antioxidant capacity than sample 4 (ABTS and ORAC-FL values, respectively). These values were not surprisingly higher than those of sample 4 for ORAC-FL value but for ABTS value antioxidant capacity increased, meaning separation by ultrafiltration seems to favor the concentration of peptides with ET mechanism for the neutralization of radicals. In addition, $\mathrm{IC}_{50}$ values were obtained for sample $4 \mathrm{LMW}(0.805 \pm 0.035$ and $0.065 \pm 0.004 \mathrm{mg} / \mathrm{mL}$ of protein for ABTS and ORAC-FL, respectively) and $\alpha$-LA $(15.732 \pm 0.256$ and $0.223 \pm 0.014 \mathrm{mg} / \mathrm{mL}$ of protein for ABTS and ORAC-FL, respectively). With these values 19.5 and 3.4 times more $\alpha$-LA than sample 4 LWM to neutralize $50 \%$ of ABTS and peroxyl radicals, respectively. The latter confirms that sample 4 LWM had a higher antioxidant capacity which increases with the percentage of hydrolysis [34]; this was confirmed by SE-HPLC (Section 3.1). Comparing sample 4 values before and after ultrafiltration it is clear that the process beneficiates the separation and concentration of the peptides that present higher antioxidant capacity (significant differences, $p<0.05$ ), evidencing the importance of using enzymatic hydrolysis as a strategy for increasing the value of whey proteins. This suggests that short peptides liberated during hydrolysis and concentrated by ultrafiltration were responsible for the antioxidant capacity as in the work of Contreras et al. [3]. These values were similar to those of other enzymes using longer time of reaction [3] [33], establishing Alcalase is more 


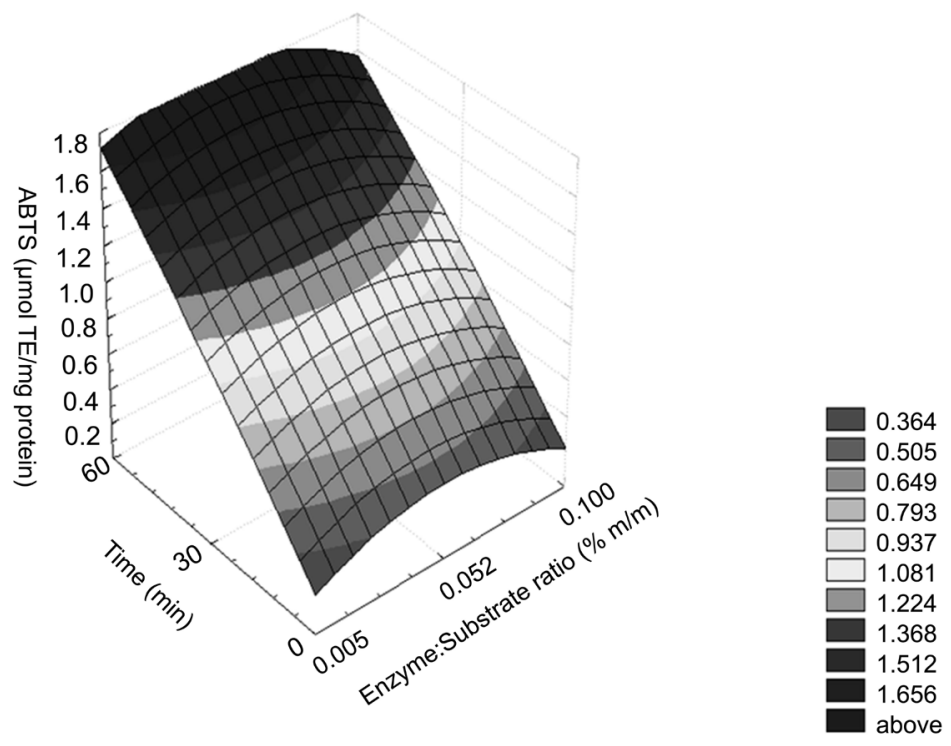

(a)

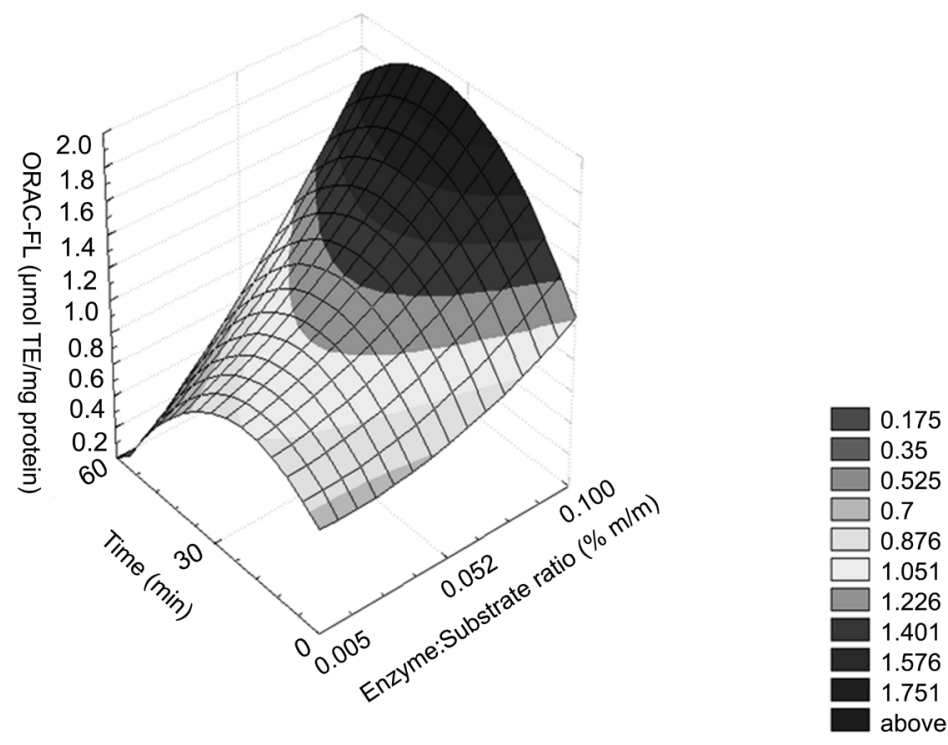

(b)

Figure 1. Surface plot of antioxidant activity of LMW $\alpha$-LA Hydrolyzates as the response variable, determined by (a) ABTS and (b) ORAC-FL methods as a function of time (minutes) and enzyme:substrate ratio $(\% \mathrm{w} / \mathrm{w})$.

efficient than other enzymes, attaining powerful antioxidant hydrolysates in less time of reaction and strengthening antioxidant capacity by obtaining short peptides through ultrafiltration.

\subsection{Antihypertensive Activity}

Regarding antihypertensive properties measured in vitro, sample 4 LMW presented 22\% of ACE inhibition percentage with respect to Captopril. This percentage is similar to the obtained for sample 4 without ultrafiltration, as reported by Fernández-Fernández et al. [10] (no significant differences). This could be 
explained by the fact that the peptides hydrolysis was not enough to release shorter peptides from $\alpha$-LA which are known to be responsible for ACE inhibitory activity [5]. Studying the effect of digestion on sample 4 LMW by in vitro simulation to demonstrate better inhibition was also observed.

\subsection{In Vitro Digestion}

As described in section2.5, in vitro digestion of $\alpha$-LA (D $\alpha$-LA, control), sample 4 (D 4) and 4 LMW (D 4 LMW) were performed in order to evaluate the effect of digestion conditions on antioxidant capacity. Characterization of each digestion was performed by determining protein content and percentage of hydrolysis by HPLC analysis (as described in Section 2.4), and antioxidant capacity determination by ABTS and ORAC-FL assays described in Section 2.6. Percentages of protein content were $50.98 \% \pm 1.80 \%, 41.48 \% \pm 0.52 \%$ and $32.65 \% \pm 1.79 \%$, for the digestion of $\alpha$-LA, sample 4 and 4 LMW, respectively. Hydrolysis percentages of the digestion of $\alpha$-LA, sample 4 and 4 LMW were $35.59 \% \pm 0.22 \%, 41.72 \%$ $\pm 0.13 \%$ and $80.89 \% \pm 0.44 \%$, respectively (Table 3 ).

According to the results obtained, it can be said that the increasing percentage of protein content of in vitro digestions resulted in diminished hydrolysis percentage. Hydrolysis percentage of the samples tends to increase with digestion related to samples without digestion (Table 3). In vitro digestion of sample 4 (D 4) showed higher hydrolysis percentage than $\alpha$-LA digestion (D $\alpha$-LA) but less than its respective LMW fraction. In vitro digestion of sample 4 LMW (D 4 LMW) showed $80 \%$ of hydrolysis (2 times fold compared to the digestion of sample 4), meaning ultrafiltration enhances hydrolysis rendering short peptides more available to digestive enzymes.

As to antioxidant capacity, $\alpha$-LA had an ABTS value of $0.191 \pm 0.007 \mu \mathrm{mol}$ $\mathrm{TE} / \mathrm{mg}$ of protein and for its in vitro digestion $0.619 \pm 0.023 \mu \mathrm{mol} \mathrm{TE} / \mathrm{mg}$ of protein increasing 3.2 times fold the antioxidant capacity (Figure 2). For both samples, 4 and $4 \mathrm{LMW}$, in vitro digestion enhanced antioxidant capacity but less than for $\alpha$-LA. Sample 4 presented an ABTS value of $1.015 \pm 0.042$ which increased to $1.115 \pm 0.049 \mu \mathrm{mol} \mathrm{TE} / \mathrm{mg}$ of protein for its in vitro digestion ( $\mathrm{p}<$ 0.05). Similarly, sample $4 \mathrm{LMW}$ presented values of $1.574 \pm 0.060$ and $1.743 \pm$ $0.086 \mu \mathrm{mol} \mathrm{TE} / \mathrm{mg}$ of protein, respectively, with significant differences as well.

For ORAC-FL assay, $\alpha$-LA presented values of $0.156 \pm 0.011 \mu \mathrm{mol} \mathrm{TE} / \mathrm{mg}$ of protein without in vitro digestion and $1.819 \pm 0.141 \mu \mathrm{mol} \mathrm{TE} / \mathrm{mg}$ of protein for

Table 3. Results of HPLC analysis of $\alpha$-LA, sample 4 and 4 LMW as well as their digestions.

\begin{tabular}{ccc}
\hline \multirow{2}{*}{ Sample } & \multicolumn{2}{c}{$\%$ Hydrolysis } \\
\cline { 2 - 3 } & Non-digested & Digested \\
\hline$\alpha$-LA & 0 & 35.59 \\
4 & 31.20 & 41.72 \\
4 LMW & 56.30 & 80.89 \\
\hline
\end{tabular}




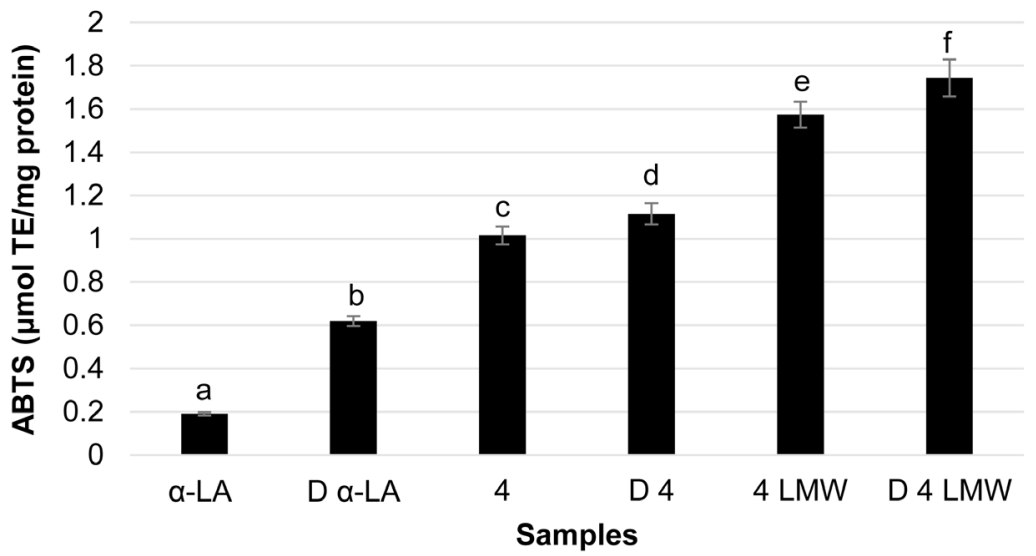

(a)

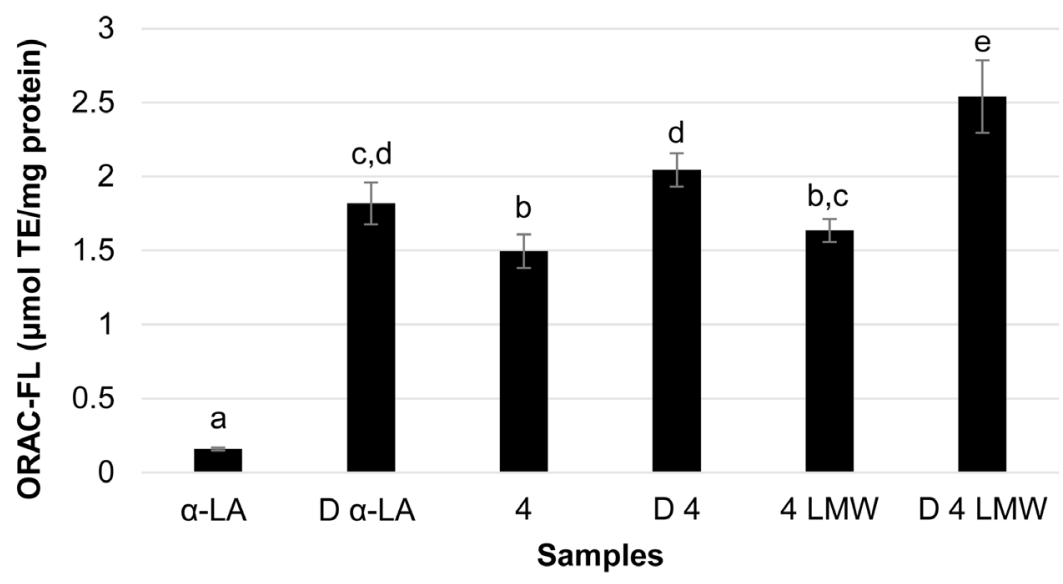

(b)

Figure 2. Graph of antioxidant capacity by ABTS assay (a) and ORAC-FL (b) of samples $\alpha$-LA, D $\alpha$-LA ( $\alpha$-LA digestion), 4, D 4 (sample 4 digestion), 4 LMW and D 4 LMW (sample 4 LMW digestion). Results are expressed as means \pm SD $(n=6)$ in $\mu \mathrm{mol} \mathrm{TE} / \mathrm{mg}$ of protein from a calibration curve with Trolox. Different letters state significant differences between ABTS and ORAC-FL values by Tukey test $(\mathrm{p}<0.05)$.

the in vitro digestion, showing a huge improvement on antioxidant capacity due to in vitro digestion (11.6 times fold). For sample 4, antioxidant capacity increased 1.4 times fold from $1.495 \pm 0.114$ (non-digested) to $2.046 \pm 0.113 \mu \mathrm{mol}$ $\mathrm{TE} / \mathrm{mg}$ of protein after in vitro digestion showing less improvement than for $\alpha$-LA. Similar results were observed for sample $4 \mathrm{LMW}$ which presented a value of $1.636 \pm 0.076$ and for its in vitro digestion $2.542 \pm 0.245 \mu \mathrm{mol} \mathrm{TE} / \mathrm{mg}$ of protein (1.5 times fold).

In both cases (ABTS and ORAC-FL), samples 4 and 4 LMW did not show great improvements on antioxidant capacity which could be explained by the fact that these had already have enzymatic hydrolysis, releasing short peptides with antioxidant properties. Thus, in vitro digestion surely enhanced hydrolysis of all samples, increases being more evident for $\alpha$-LA. Overall, samples with in vitro digestion showed increased hydrolysis as well as for non-digested 4 and 4 
LMW ( $\mathrm{p}<0.05$ ) with the associated improvement of antioxidant capacity making encrypted peptides more bioaccessible by in vitro digestion. These results agree with those of Adjonu et al. [35], Ranamukhaarachchi et al. [36], Saavedra et al. [21] and Tavares et al. [37] that highlighted the importance of enzymatic hydrolysis as the reason why antioxidant capacity increases due to release of encrypted short peptides release from $\alpha$-LA native sequence. In our study, enzymatic hydrolysis was enhanced by gastrointestinal tract enzymes, improving antioxidant capacity. Thus, we aimed at understanding whether the digested hydrolysate provokes cell metabolic activity improvement. This would state that short peptides could be able to produce beneficial effects on intestinal epithelium. For this reason, cell metabolic activity on intestinal cells was measured.

\subsection{Cell Studies}

MTT assay was performed on TC7-cells after $1 \mathrm{~h}$ incubation in the presence of sample $4 \mathrm{LMW}$ and its in vitro digestion (D $4 \mathrm{LMW}$ ) counterpart standing for the hydrolysates and the in vitro digestion of the hydrolysates that presented the best antioxidant capacity, respectively. Results in Figure 3 show that cell metabolic activity of non-digested hydrolysates in concentrations 1,5 and $10 \mathrm{mg} / \mathrm{mL}$ of protein did not differ from the control (HBSS) ( $p<0.05)$ stating 4 LMW is not cytotoxic for intestinal cells at the tested concentrations. Conversely, digested hydrolysates presented increments at $5 \mathrm{mg} / \mathrm{mL}$ of protein implying an increase in the absorption of digested peptides (D 4 LMW) compared to non-digested peptides (4 LMW). Concentration of $10 \mathrm{mg} / \mathrm{mL}(4 \mathrm{LMW})$ did not differ from control samples but D 4 LMW decreased cell metabolic activity compared to concentration of $5 \mathrm{mg} / \mathrm{mL}$. Moreover, concentration of $20 \mathrm{mg} / \mathrm{mL}$ (D 4 LMW) presented less cell metabolic activity than control meaning that

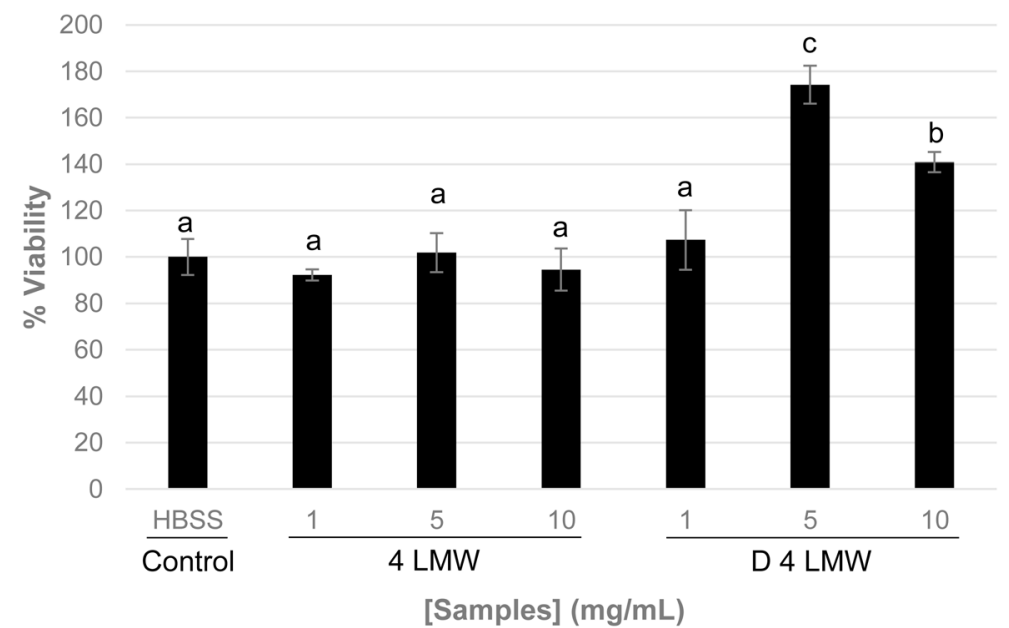

Figure 3. Cell viability determinations by MTT assay measuring absorbance at $570 \mathrm{~nm}$ for the control (HBSS) and different concentrations $(\mathrm{mg} / \mathrm{mL}$ of protein) of sample 4 LMW and D 4 LMW. Results are expressed as means \pm SD $(n=3)$ in \% viability taking HBSS absorbance values as $100 \%$. Different letters state significant differences between $\%$ viability by Tukey test $(\mathrm{p}<0.05)$. 
Concentrations higher than $5 \mathrm{mg} / \mathrm{mL}$ may overcharge cell metabolism and diminish cell metabolic activity (data not shown). Clearly, D 4 LMW had a positive effect on cell metabolism up to concentrations of $5 \mathrm{mg} / \mathrm{mL}$. For non-digested $4 \mathrm{LMW}$, concentrations tested seemed not to beneficiate cell metabolism. This could be explained by the fact that sample 4 LMW contain longer peptides unable to enter the intestinal cells and increase cell metabolic activity (for $1 \mathrm{~h}$ time of exposure). Digestion appears to enhance bioaccessibility of peptides within 4 LMW structure with the consequent increase in the bioavailability. In other research, Xie et al. [38] studied the bioavailability of low molecular weight peptides of casein hydrolysates using Alcalase enzyme after simulated gastrointestinal digestion. In the latter work they found that digested Alcalase hydrolysates were bioavailable because of the low molecular weight peptides. Moreover, low molecular weight fraction was the most bioavailable of the fractions being in accordance with the increase detected in the present study for the D 4 LMW that suffered more hydrolysis and generated shorter peptides more easily absorbed. In addition, low molecular weight fraction was also found to present the highest antioxidant capacity after simulated gastrointestinal digestion and absorption in TC7-cells for which D 4 LMW could be able to exert its antioxidant effect after absorption or over intestinal cells helping to maintain an antioxidant environment in the lumen of the intestine. Overall, these results state that D 4 LMW enhanced cell metabolism showing relevance for intestinal cells health. Further research is being carried out by our team regarding the incorporation of the isolated $4 \mathrm{LMW}$ and D $4 \mathrm{LMW}$ peptides into dairy foods using spraydrying and lyposomes as carriers. In vivo studies could provide data related to actual bioavailability of the isolates.

\section{Conclusion}

The effect of ultrafiltration of different enzyme:substrate ratio and time conditions on antioxidant capacity of $\alpha$-LAhydrolysates using Alcalase was evaluated using response surface methodology. The highest antioxidant capacity was found in the ultrafiltrated hydrolysate with $0.1 \% \mathrm{w} / \mathrm{w}$ for enzyme:substrate ratio and 60 minutes time of reaction (sample 4 LMW). Using this methodology, it was demonstrated that reaction time had a positive influence on antioxidant capacity measured by ABTS and ORAC-FL methods. Moreover, enzyme:substrate ratio had a positive influence on antioxidant capacity measured by ORAC-FL. Enhanced antioxidant capacity was explained by more hydrolysis (release of shorter peptides), confirmed by SE-HPLC. A pool of short peptides in sample 4 LMW could be responsible for these high antioxidant capacities. In contrast, low ACE-inhibitory activity was found in sample 4 LMW likely because hydrolysis did not release the tripeptides responsible for these activities. In vitro simulation of gastrointestinal digestion of $\alpha$-LA, sample 4 and 4 LMW was found to increase hydrolysis with the association of enhanced antioxidant capacity as well as intestinal cell metabolic activity. By simulated digestion, it was shown that diges- 
tion improves bioaccessibility with consequent improved cell metabolic activity of bioactive peptides revealing hydrolysate $4 \mathrm{LMW}$ as a promising functional ingredient.

\section{Acknowledgements}

The research that gives rise to the results presented in this publication received funding from the National Agency for Research and Innovation under the code POS_NAC_2013_1_11655, from the Fondo Vaz Ferreira funded project I/FVF2017/189 (Desarrollo de micro y nanovehículos de péptidos bioactivos como ingredientes funcionales para una alimentación saludab) and from ECOS-Sud Committee funded project U08B01 (Procedimientos Innovadores y valorización de compuestos bioactivos destinados a la industria alimentaria, con particular atención en la industria láctea). The authors would like to acknowledge Françoise Lazennec of Université de Montpellier for her technical contribution in celular studies; Paula Aphalo and María Cristina Añón of the Centro de Investigación y Desarrollo en Criotecnología de Alimentos (CIDCA) (CCT La Plata, CONICET), Facultad de Ciencias Exactas, Universidad Nacional de La Plata (UNLP), 47 y 116 (1900), La Plata, Argentina for their technical assistance; and Laboratorio de Fisicoquímica Biológica (Instituto Química Biológica, Facultad de Ciencias, UdelaR) for the loan of equipment.

\section{Conflicts of Interest}

The authors declare no conflicts of interest regarding the publication of this paper.

\section{References}

[1] Prior, R.L. (2015) Oxygen Radical Absorbance Capacity (ORAC): New Horizons in Relating Dietary Antioxidants/Bioactives and Health Benefits. Journal of Functional Foods, 18, 797-810. https://doi.org/10.1016/j.jff.2014.12.018

[2] Halliwell, B. and Gutteridge, J.M. (1984) Oxygen Toxicity, Oxygen Radicals, Transition Metals and Disease. The Biochemical Journal, 219, 1-14.

https://doi.org/10.1042/bj2190001

[3] Contreras, M.D.M., Hernández-Ledesma, B., Amigo, L., Martín-Álvarez, P.J. and Recio, I. (2011) Production of Antioxidant Hydrolyzates from a Whey Protein Concentrate with Thermolysin: Optimization by response Surface Methodology. LWT-Food Science and Technology, 44, 9-15. https://doi.org/10.1016/j.lwt.2010.06.017

[4] Zulueta, A., Esteve, M.J. and Frígola, A. (2009) ORAC and TEAC Assays Comparison to Measure the Antioxidant Capacity of Food Products. Food Chemistry, 114, 310-316. https://doi.org/10.1016/j.foodchem.2008.09.033

[5] Hernández-Ledesma, B., Amigo, L., Ramos, M. and Recio, I. (2004) Release of Angiotensin Converting Enzyme-Inhibitory Peptides by Simulated Gastrointestinal Digestion of Infant Formulas. International Dairy Journal, 14, 889-898. https://doi.org/10.1016/j.idairyj.2004.02.011

[6] Marshall, K. (2004) Therapeutic Application of Whey Protein. Alternative Medicine 
Review, 9, 136-156.

[7] Vatani, D.S and Golzar, F.A.K. (2012) Changes in Antioxidant Status and Cardiovascular Risk Factors of Overweight Young Men after Six Weeks Supplementation of Whey Protein Isolate and Resistance Training. Appetite, 59, 673-678. https://doi.org/10.1016/j.appet.2012.08.005

[8] Sadat, L., Cakir-Kiefer, C., N'Negue, M.-A., Gaillard, J.-L., Girardet, J.-M. and Miclo, L. (2011) Isolation and Identification of Antioxidative Peptides from Bovine $\alpha$-Lactalbumin. International Dairy Journal, 21, 214-221. https://doi.org/10.1016/j.idairyj.2010.11.011

[9] Fritz, M., Vecchi, B., Rinaldi, G. and Añón, M.C. (2011) Amaranth Seed Protein Hydrolysates Have in Vivo and in Vitro Antihypertensive Activity. Food Chemistry, 126, 878-884. https://doi.org/10.1016/j.foodchem.2010.11.065

[10] Fernández-Fernández, A.M., López-Pedemonte, T. and Medrano-Fernandez, A. (2017) Evaluation of Antioxidant, Antiglycant and ACE-Inhibitory Activity in Enzymatic Hydrolysates of $\alpha$-Lactalbumin. Food and Nutrition Sciences, 8, 84-98. https://doi.org/10.1016/j.foodchem.2010.11.065

[11] Madureira, A.R., Tavares, T., Gomes, A.M.P., Pintado, M.E. and Malcata, F.X. (2010) Invited Review. Physiological Properties of Bioactive Peptides Obtained from Whey Proteins. Journal of Dairy Science, 93, 437-455. https://doi.org/10.3168/jds.2009-2566

[12] Korhonen, H. and Pihlanto, A. (2006) Bioactive Peptides: Production and Functionality. International Dairy Journal, 16, 945-960. https://doi.org/10.1016/j.idairyj.2005.10.012

[13] Pihlanto-Leppälä, A., Koskinen, P., Piilola, K., Tupasela, T. and Korhonen, H. (2000) Angiotensin I-Converting Enzyme Inhibitory Properties of Whey Protein Digests: Concentration and Characterization of Active Peptides. Journal of Dairy Research, 67, 53-64. https://doi.org/10.1017/S0022029999003982

[14] O'Loughlin, I.B., Murray, B.A., Brodkorb, A., FitzGerald, R.J. and Kelly, P.M. (2014) Production of Whey Protein Isolate Hydrolysate Fractions with Enriched ACE-Inhibitory Activity. International Dairy Journal, 38, 101-103. https://doi.org/10.1016/j.idairyj.2013.12.008

[15] Torino, M.I., Limón, R.I., Martínez-Villaluenga, C., Mäkinen, S., Pihlanto, A., Vidal-Valverde, C. and Frias, J. (2013) Antioxidant and Antihypertensive Properties of Liquid and Solid State Fermented Lentils. Food Chemistry, 136, 1030-1037. https://doi.org/10.1016/j.foodchem.2012.09.015

[16] de Vos, P., Faas, M.M., Spasojevic, M. and Sikkema, J. (2010) Encapsulation for Preservation of Functionality and Targeted Delivery of Bioactive Food Components. International Dairy Journal, 20, 292-302.

https://doi.org/10.1016/j.idairyj.2009.11.008

[17] Hollebeeck, S., Borlon, F., Schneider, Y.-J., Larondelle, Y. and Rogez, H. (2013) Development of a Standardised Human in Vitro Digestion Protocol Based on Macronutrient Digestion Using Response Surface Methodology. Food Chemistry, 138, 1936-1944. https://doi.org/10.1016/j.foodchem.2012.11.041

[18] Picariello, G., Mamone, G., Nitride, C., Addeo, F. and Ferranti, P. (2013) Protein Digestomics: Integrated Platforms to Study Food-Protein Digestion and Derived Functional and Active Peptides. Trends in Analytical Chemistry, 52, 120-134. https://doi.org/10.1016/j.trac.2013.08.001

[19] McClements, D.J. (2015) Encapsulation, Protection, and Release of Hydrophilic Active Components: Potential and Limitations of Colloidal Delivery Systems. Ad- 
vances in Colloid and Interface Science, 219, 27-53.

https://doi.org/10.1016/j.cis.2015.02.002

[20] Singh, H., Ye, A. and Horne, D. (2009) Structuring Food Emulsions in the Gastrointestinal Tract to Modify Lipid Digestion. Progress in Lipid Research, 48, 92-100. https://doi.org/10.1016/j.plipres.2008.12.001

[21] Saavedra, L., Hebert, E.M., Minahk, C. and Ferranti, P. (2013) An Overview of "Omic" Analytical Methods Applied in Bioactive Peptide Studies. Food Research International, 54, 925-934. https://doi.org/10.1016/j.foodres.2013.02.034

[22] Xie, N., Wang, B., Jiang, L., Liu, C. and Li, B. (2015) Hydrophobicity Exerts Different Effects on Bioavailability and Stability of Antioxidant Peptide Fractions from Casein during Simulated Gastrointestinal Digestion and Caco-2 Cell Absorption. Food Research International, 76, 518-526. https://doi.org/10.1016/j.foodres.2015.06.025

[23] Box, G.E.P., Hunter, J.S. and Hunter, W.G. (1978) Statistics for Experimenters. An Introduction to Design, Data Analysis, and Model Building. John Wiley \&Sons, New York.

[24] Lowry, O., Rosebrough, N., Farr, A. and Randall, R. (1951) Protein Measurement with the Folin-Phenol Reagent. Journal of Biological Chemistry, 193, 265-275.

[25] Molina Ortiz, S.E. (1997) Modificación enzimática de propiedades funcionales de aislados proteicos de soja. Tesis Doctoral, Universidad Nacional de la Plata, Facultad de Ciencias Exactas, Departamento de Química.

[26] Re, R., Pellegrini, N., Proteggente, A., Pannala, A., Yang, M. and Rice-Evans, C. (1999) Antioxidant Activity Applying an Improved ABTS Radical Cationdecolorization Assay. Free Radical Biology \& Medicine, 26, 1231-1237. https://doi.org/10.1016/S0891-5849(98)00315-3

[27] Ou, B., Hampsch-woodill, M. and Prior, R. (2001) Development and Validation of an Improved Absorbance Capacity Assay Using Fluorescein as the Fluorescent. Journal of Agriculture and Food Chemistry, 49, 4619-4626. https://doi.org/10.1021/jf010586o

[28] Dávalos, A., Bartolomé, B. and Gómez-Cordovés, C. (2005) Antioxidant Properties of Commercial Grape Juices and Vinegars. Food Chemistry, 93, 325-330. https://doi.org/10.1016/j.foodchem.2004.09.030

[29] Cushman, D.W. and Cheung, H.S. (1971) Spectrophotometric Assay and Properties of the Angiotensin-Converting Enzyme of Rabbit Lung. Biochemical Pharmacology, 20, 1637-1648. http://www.ncbi.nlm.nih.gov/pubmed/4355305 https://doi.org/10.1016/0006-2952(71)90292-9

[30] Kim, Y., Yoon, S., Yu, D., Lönnerdal, B. and Cheung, B. (1999) Novel Angiotensin-I-Converting Enzyme Inhibitory Peptides Derived from Recombinant Human as1-casein Expressed in Escherichia Coli. Journal of Dairy Research, 66, 431-439. https://doi.org/10.1017/S0022029999003556

[31] Benzaria, A., Gràcia-Julià, A., Picart-Palmade, L., Hue, P., Chevalier-Lucia, D., Marti-Mestres, G., Hodor, N. and Dumay, E. (2014) UHPH-Processed O/W Submicron Emulsions Stabilised with a Lipid-Based Surfactant: Physicochemical Characteristics and Behaviour on in Vitro TC7-Cell Monolayers and ex Vivo Pig's Ear Skin. Colloids and Surfaces B: Biointerfaces, 116, 237-246. https://doi.org/10.1016/j.colsurfb.2013.12.050

[32] Benzaria Benzaria, A., Maresca, M., Taieb, N. and Dumay, E. (2013) Interaction of Curcumin with Phosphocasein Micelles Processed or Not by Dynamic High-Pressure. Food Chemistry, 138, 2327-2337. 
https://doi.org/10.1016/j.foodchem.2012.12.017

[33] Adjonu, R., Doran, G., Torley, P. and Agboola, S. (2013) Screening of Whey Protein Isolate Hydrolysates for Their Dual Functionality: Influence of Heat Pre-Treatment and Enzyme Specificity. Food Chemistry, 136, 1435-1443.

https://doi.org/10.1016/j.foodchem.2012.09.053

[34] Saadi, S., Saari, N., Anwar, F., Abdul Hamid, A. and Ghazali, H.M. (2015) Recent Advances in Food Biopeptides: Production, Biological Functionalities and Therapeutic Applications. Biotechnology Advances, 33, 80-116.

https://doi.org/10.1016/j.biotechadv.2014.12.003

[35] Adjonu, R., Doran, G., Torley, P. and Agboola, S. (2014) Whey Protein Peptides as Components of Nanoemulsions: A Review of Emulsifying and Biological Functionalities. Journal of Food Engineering, 122, 15-27.

https://doi.org/10.1016/j.jfoodeng.2013.08.034

[36] Ranamukhaarachchi, S., Meissner, L. and Moresoli, C. (2013) Production of Antioxidant Soy Protein Hydrolysates by Sequential Ultrafiltration and Nanofiltration. Journal of Membrane Science, 429, 81-87. https://doi.org/10.1016/j.memsci.2012.10.040

[37] Tavares, T.G., Amorim, M., Gomes, D., Pintado, M.E., Pereira, C.D. and Malcata, F.X. (2012) Manufacture of Bioactive Peptide-Rich Concentrates from Whey: Characterization of Pilot Process. Journal of Food Engineering, 110, 547-552. https://doi.org/10.1016/j.jfoodeng.2012.01.009

[38] Xie, N., Wang, C., Ao, J. and Li, B. (2013) Non-Gastrointestinal-Hydrolysis Enhances Bioavailability and Antioxidant Efficacy of Casein as Compared with Its in Vitro Gastrointestinal Digest. Food Research International, 51, 114-122. https://doi.org/10.1016/j.foodres.2012.12.001 